Research Note

\title{
SINGLE STEM CULTIVATION AND PERFORMANCE OF CUCUMBER CULTIVARS DURING WINTER-SPRING SEASONS
}

\author{
P. P. Subedi and M. D. Sharma \\ Institute of Agriculture and Animal Sciences, Rampur, Chitwan, Nepal
}

\begin{abstract}
This experiment was conducted to assess the response of three cucumber cultivars Bhaktapur Local, Japanese Green and Korean White to single stem cultivation in randomized block design with six replications. The experiment was conducted in Yampaphant (450 m asl) during December 2001 to April 2002. The cv. Bhaktapur Local produced significantly higher number of male flowers $\left(32 / \mathrm{m}^{2}\right)$, while the Korean White produced significantly higher number of female flowers $\left(37.5 / \mathrm{m}^{2}\right)$ and a very few number of male flowers. The cv. Korean White produced significantly higher number of marketable fruits $\left(20 / \mathrm{m}^{2}\right)$ and higher marketable yield (48.2 t/ ha) followed by Japanese Green ( $45.7 \mathrm{t} / \mathrm{ha})$. The cv. Bhaktapur Local produced the lowest marketable yield (33.3 t/ha). Hence single stem cultivation performed well in winter-spring season.
\end{abstract}

Key words: Cucumber cultivars, single stem cultivation, late winter-spring

\section{INTRODUCTION}

The landraces and improved cultivars of cucumber mostly gown in Nepal belong to the monoecious phenotype. Such cultivars are mainly adapted to the main season cultivation when the favorable weather conditions are available for luxuriant growth of the plant. In the open field cultivation, prunning may be practiced for the promotion of female flower production. Often, the main vine of the monoecious cucumber bears only staminate flowers on the basal nodes, staminate and pistillate flowers alternately or mixed on the middle and mostly pistillate flowers on the upper part of the vine. The secondary and tertiary vines have a tendency to produce more number of pistillate flowers than staminate. Hence, in the monoecious phenotype, pinching off the apical part of the main vine is practiced twice for the promotion of tertiary sprout and its cultivation (Pantielev, 1981).

In short day and cool air temperature conditions of winter, the monoecious phenotype cultivars start to bear female flowers from the basal nodes even on the main vine. The main vine produces sufficient number of female flowers to have optimum yield. Under protected cultivation in winter, side shoots are pruned in order to accommodate more number of plants in limited space. During the normal season, prunning of basal laterals decreases early yield in trellised plots (Konsler and Strider, 1973). Review of literature showed that the single stem cultivation promotes early and market quality fruits, and also makes convenient for conducting intercultural operations. Therefore, this study was conducted to assess the response of commercial and promising cucumber cultivars to single stem cultivation under open field condition.

\section{MATERIALS AND METHODS}

This experiment was conducted in a randomized block design with six replications during December 2001 to April 2002. The size of the individual plot was $2.4 \mathrm{~m}^{2}$, consisting of 4 plants. Three cucumber cultivars, such as Japanese Green, Korean White and Bhaktapur Local were included in the study. Seeds of these cultivars were sown on December 23, 2001 in plastic pots filled with soil and well-decomposed manure in the proportion of 1:1 by volume. Seedlings were raised under the plastic tunnel. Two sprays of Dithane M-45 and single spray of Miraculan (plant growth promoter) were applied at nursery stage. Pits were dug and $4 \mathrm{~kg}$ farmyard manure, 20 $\mathrm{g}$ diammonium phosphate and $18 \mathrm{~g}$ murate of potash per pit were applied the time of pit filling. Seedlings at 3-4 true leaf stages were transplanted on January 2, 2002. Side dressing was done regularly with $5 \mathrm{~g}$ urea per plant at 10 days interval. The first side dress was applied at 25 days after transplanting. Multiplex was sprayed seven times during flowering and fruiting period at 7-15 days interval. Each plant was staked separately with 2.5 $\mathrm{m}$ tall bamboo split. The plants were loosely tied to the stake with a piece of jute rope. The side shoots, i.e. just emerging lateral vines in the main stem above the first leaf were pinched off. 
Parameters observed included plant stand, duration from sowing to first male and female flower initiation, first male and female flower bearing node number, total male and female flowers per $\mathrm{m}^{2}$, total number of nodes and branches per plant, biomass $\left(\mathrm{kg} / \mathrm{m}^{2}\right)$ and number of fruit set per $\mathrm{m}^{2}$, harvest duration and number, marketable fruits $/ \mathrm{m}^{2}$ and yield ( $\mathrm{t} / \mathrm{ha}$ ). MSTAT computer software was used to analyze the data.

\section{RESULTS AND DISCUSSION}

\section{Plant stand and sex expression}

The results of various parameters are presented in Table 1. Four seedlings were planted in each plot and almost all the seedlings developed good vines and produced fruits. The cv. Korean White produced the first pistillate flower in the shortest period $(66$ DAS) $(\mathrm{p}<0.05)$ than Japanese Green and Bhaktapur Local. The cv. Bhaktapur Local produced female flowers significantly later at 78 DAS. The Korean White produced the first pistillate flower at $3^{\text {rd }}$ node, while Japanese Green and Bhaktapur Local at $4^{\text {th }}$ and $8^{\text {th }}$ nodes, respectively. Similarly, the $\mathrm{cv}$. Bhaktapur Local produced significantly higher number of male flowers $\left(32 / \mathrm{m}^{2}\right)$ followed by Japanese Green $\left(6.9 / \mathrm{m}^{2}\right)$. On the contrary, the Korean White produced significantly the highest number of female flowers $\left(37.5 / \mathrm{m}^{2}\right)$ followed by Japanese Green $\left(29 / \mathrm{m}^{2}\right)$. Hence, Korean White produced the highest number of female flowers and a very few number of male flowers and behaved as a gynoecious cultivar. The Japanese Green produced more than 4 times higher number of female flowers than male flowers, while Bhaktapur Local produced higher number of male flowers than female flowers.

Table 1. Flowering behavior and morphological characters of three cucumber cultivars in single stem cultivation at Yampaphant, Tanahun in late winter-spring of 2002

\begin{tabular}{|c|c|c|c|c|c|c|c|c|c|}
\hline Cultivars & $\begin{array}{l}\text { Plant stand } \\
\text { per plot at } \\
\text { harvest }\end{array}$ & $\begin{array}{l}\text { Days to } \\
\text { first } \\
\text { pistillate } \\
\text { flower }\end{array}$ & $\begin{array}{c}\text { First } \\
\text { pistillate } \\
\text { flowering } \\
\text { node }\end{array}$ & $\begin{array}{c}\text { Total male } \\
\text { flowers } \\
\text { per } \mathrm{m}^{2}\end{array}$ & $\begin{array}{c}\text { Total female } \\
\text { flowers } \\
\text { per } \mathrm{m}^{2}\end{array}$ & $\begin{array}{l}\text { Total nodes } \\
\text { per plant }\end{array}$ & $\begin{array}{c}\text { Total } \\
\text { branches } \\
\text { per plant }\end{array}$ & $\begin{array}{l}\text { Plant } \\
\text { height } \\
\text { (m) }\end{array}$ & $\begin{array}{l}\text { Above } \\
\text { ground } \\
\text { mass } \\
\left(\mathrm{kg} / \mathrm{m}^{2}\right)\end{array}$ \\
\hline Japanese Green & 3.833 & $71 \mathrm{~b}$ & 4.000 & $6.9 \mathrm{~b}$ & $29.0 \mathrm{~b}$ & $105 b$ & 17.0 & $7.4 \mathrm{~b}$ & 0.71 \\
\hline Korean White & 4.000 & $66 \mathrm{c}$ & 3.000 & $0.48 \mathrm{c}$ & $37.5 \mathrm{a}$ & $107 \mathrm{~b}$ & 12.5 & $8.4 \mathrm{~b}$ & 0.57 \\
\hline Bhaktapur Local & 3.833 & $78 \mathrm{a}$ & 4.833 & $32.0 \mathrm{a}$ & $21.6 c$ & $116 \mathrm{a}$ & 54.83 & $12.1 \mathrm{a}$ & 1.3 \\
\hline LSD 5\% & ns & 3.997 & ns & 3.8 & 6.4 & 7.433 & - & 1.280 & - \\
\hline SME \pm & 0.1427 & 1.2686 & 0.5037 & 2.9342 & 4.9158 & 2.3590 & 1.8038 & - & 0.1139 \\
\hline CV 8.99 & 4.34 & 31.28 & 22.78 & 17.05 & 5.29 & 15.72 & - & 13.68 & \\
\hline
\end{tabular}

\section{Morphological characters and biomass}

The Japanese Green and the Korean White had similar number of nodes. However, the. Bhaktapur Local had significantly higher number of nodes (116/plant) than Japanese Green (107/plant) and Korean White (105/plant). Similarly, the Bhaktapur Local had significantly longer vine $(12.1 \mathrm{~m})$ and the vine had significantly very high number of branches. Among the tested cultivars, Bhaktapur Local produced the highest number of branches (55 branches/vine) and the highest amount of above ground biomass $\left(1.3 \mathrm{~kg} / \mathrm{m}^{2}\right)$ followed by Japanese Green $\left(0.71 \mathrm{~kg} / \mathrm{m}^{2}\right)$ and Korean White $\left(0.57 \mathrm{~kg} / \mathrm{m}^{2}\right)$. The results confirmed that high vigor cultivar produced the higher number of male flowers than female flowers.

\section{Harvest behavior and yield components}

The number of fruit set is the yield attributing parameter. The highest number of fruit set $\left(24.4 / \mathrm{m}^{2}\right)$ was observed in Korean White and the lowest $\left(13.5 / \mathrm{m}^{2}\right)$ in Bhaktapur Local. In the Bhaktapur Local, the first harvest was one week later than in Korean White and Japanese Green, however, the last harvest date was not different in all the cultivars tested in this season. The number of harvests was significantly greater in Japanese Green and Korean White than in Bhaktapur Local. The Korean White and Japanese Green produced significantly higher number of fruits $\left(\right.$ per $\mathrm{m}^{2}$ ) than Bhaktapur Local (Table 2). 
Table 2. Harvest behavior and yield of three cucumber cultivars in single stem cultivation at Yampaphant, Tanahun in late winter-spring of season, 2002

\begin{tabular}{|lcccccc|}
\hline Cultivars & Fruit set per $\mathrm{m}^{2}$ & $\begin{array}{c}\text { Days to first } \\
\text { harvest }\end{array}$ & $\begin{array}{c}\text { Days to last } \\
\text { harvest }\end{array}$ & $\begin{array}{c}\text { Harvest } \\
\text { frequencies }\end{array}$ & $\begin{array}{c}\text { Marketable } \\
\text { fruits } / \mathrm{m}^{2}\end{array}$ & $\begin{array}{c}\text { Marketable } \\
\text { yield } \mathbf{t} / \text { ha }\end{array}$ \\
\hline Japanese Green & 20.6 & 82 & 116 & $9 \mathrm{a}$ & $17.3 \mathrm{a}$ & $45.7 \mathrm{a}$ \\
Korean White & 24.4 & 82 & 116 & $9 \mathrm{a}$ & $19.9 \mathrm{a}$ & $48.2 \mathrm{a}$ \\
Bhaktapur Local & 13.5 & 89 & 116 & $7 \mathrm{~b}$ & $10.3 \mathrm{~b}$ & $33.3 \mathrm{~b}$ \\
LSD 5\% & - & 1.993 & $\mathrm{~ns}$ & $\mathrm{~s}$ & 4.055 & 9.36 \\
SME \pm & 3.0182 & 0.6325 & 0.0 & 0.2108 & 3.0885 & 0.7128 \\
CV & 15.80 & 1.84 & 0.0 & 6.20 & 19.91 & 17.16 \\
\hline
\end{tabular}

Similarly, both these cultivars produced significantly higher marketable yield than Bhaktapur Local. The Korean White was the highest yielder (48.2 $\mathrm{t} / \mathrm{ha}$ ) followed by Japanese Green (45.7 t/ha) and the lowest yielder was Bhaktapur Local (33.3 t/ha). The Bhaktapur Local may be cultivated with Korean White as a pollenizer variety in the tunnel cultivation during winter. Mary (2002) noted that pollination in gynoecious crops is ensured by blending seed of a monoecious cultivar (pollenizer) with seed of the gynoecious hybrid. It may be concluded that the Korean White and Japanese Green performed better than Bhaktapur Local. Single stem cultivation can be practiced in winter sown cucumber to improve yield and quality of the crop. In Nepal, commercial cucumber cultivars. such as Green Long and Poinsett have been suggested for terai, while Kusule and Bhaktapur Local for hills for spring-summer crop (Pander and Adhikari, 1996). The performance of these varieties when planted in summer- rainy seasons remained poor because of preponderance of maleness (Subedi et al., 1997). The cv. Bhaktapur Local also performed well by producing $33.3 \mathrm{t}$ fruits/ha in single stem cultivation during late winterspring seasons. Hence, the single stem cultivation may be practiced during late winter-spring seasons.

\section{ACKNOWLEDGEMENTS}

This study was the piece of the research project 'Light and temperature induced stress management for off season cucumber production' (HARP 105/99) operated in 1999-2002 under the financial support of the Hill Agriculture Research Project funded by the British Government Department for International Development (DFID).

\section{REFERENCES CITED}

Konsler, T. R. and D. L. Strider. 1973. The response of cucumber to trellis vs. ground culture. Hort. Sci. 8(3): 220-221.

Mary, P. 2002. Crop profiles - cucumber. Sustainable practices for vegetable production in the south. http:// www.cals.ncsu.edu/sustainable/peet/profiles/clocuke.html.

Pandey, I. R. and K. P, Adhikari. 1996. Research for vegetable development in Nepal. Paper presented at the National Seminar on Vegetable Development, 11-12 June, 1996. Vegetable Development Division, Lalitpur, Nepal.

Pantielev, Y. X. 1981. Peri-urban vegetable production. Moscow, Kolos (Russian).

Subedi, P. P., S. P. Bhattarai and J. P. Jaiswal. 1997. Increase female flower frequencies of cucumber cv. Bhaktapur Local 1996. LARC Working Paper No. 97/28. Lumle Agriculture Research Centre, Kaski, Nepal. 